\title{
The role of phenolic compounds in the determination of wilt disease tolerance of oil palm (Elaeis guineensis JACQ)
}

\author{
Diabate, $\mathrm{S}^{1 \star}{ }^{1 \star}$ Franqueville, $\mathrm{H}(\mathrm{De})^{2}$, Adon, $\mathrm{B}^{3}$, Coulibaly, O. A. ${ }^{4}$ and Ake, $\mathrm{S}^{5}$ \\ ${ }^{1}$ CNRA, Laboratoire Central de Biotechnologies 01 BP 1740 Abidjan 01 Cote D'Ivoire. \\ ${ }^{2}$ CIRAD, TA 80 /02, Avenue Agropolis F 34398 Montpellier Cedex 5 France. \\ ${ }^{3}$ CNRA, Station de Recherche de La Mé 13 BP 989 Abidjan 13 Cote D'Ivoire. \\ ${ }^{4}$ CNRA, Station D'expérimentation et de Production BP 8 Dabou Cote D'ivoire. \\ ${ }^{5}$ UFR Biosciences, Université de Cocody 22 BP 582 Abidjan 22 Cote D'Ivoire.
}

Accepted 30 April, 2009

\begin{abstract}
Oil palm defence reaction to the vascular wilt disease was characterized by the production of phenolic compounds in the roots and pseudobulbs infected at the prenursery stage. The study was aimed at discriminating between tolerant and sensitive ones by the phenolic reaction of the roots and pseudobulbs after their infection with the Fusarium oxysporum f.sp.elaeidis, the pathogenic agent of vascular wilt disease of oil palm. Principal Component Analysis (PCA) and Discriminant Analysis (DA) show that although the phenolic metabolism was different in both organs; all the phenols belonged to the flavonoids and can be used to distinguish the tolerant clones and sensitive ones.
\end{abstract}

Key words: Oil palm, wilt disease, pseudobulb, phenols, flavonoids.

\section{INTRODUCTION}

The vascular wilt disease, caused by Fusarium oxysporum f. sp. elaeidis is considered to be the most serious disease of oil palm in Africa. It was first described in the Democratic republic of Congo (former Belgian Congo) in 1946. It was then described in the major oil palm countries in West Africa: Côte d'Ivoire, Ghana, Benin, Nigeria and Cameroon (Wardlaw, 1946; Bachy and Fehling 1957; Meunier et al., 1979; Renard and Quillec 1984). Wild oil palm groves were generally free from vascular wilt, while more than $50 \%$ of losses could be recorded on mature palm plantations. On average, losses were estimated to range between 1 and $2 \%$ per year. Recovery was frequently observed when tolerant/resistant materiel was planted. Vascular wilt has been generally more severe in replanting, where it has been a disease of immature palms because the inoculum built-up during the first planting (De Franqueville, 1990). There are two types of symptoms on mature palms: acute symptom, generally leading to death within 6 months after they appear

*Corresponding author. E-mail: sekou_diabate2002@yahoo.fr.
(Figure 1) and chronic symptom, stopping the growth of the palm which bears very few and very poor bunches (Figure 2) .There is no chemical treatment economically viable. The privileged means of control without which oil palm could not be grown in wilt disease areas without major risk, remained the selection of tolerant crosses and clones (Renard et al., 1980).

This research about tolerant crosses and clones is based on tests of inoculation of the Fusarium oxysporum f. sp. elaeidis at prenursery stage. The results were obtained 5 months after inoculation and are correlated with field results. Every cross or clone tested is characterised by a nursery wilt index: when the wilt index was inferior to 100 , the cross or clone was resistant, if the wilt index was superior to 100 , the cross or clone was susceptible (sensitive). This selection method can be used to detect many sources of tolerance in the descendances of crosses as well as in the clones. This selection is completed now by the research about biochemical components from the phenolic reaction of the crosses or clones infected by the pathogen (Taquet, 1985; Diabaté et al., 1990). The researches have shown that the defence reaction of oil palm against the pathogenic agent of wilt disease was 


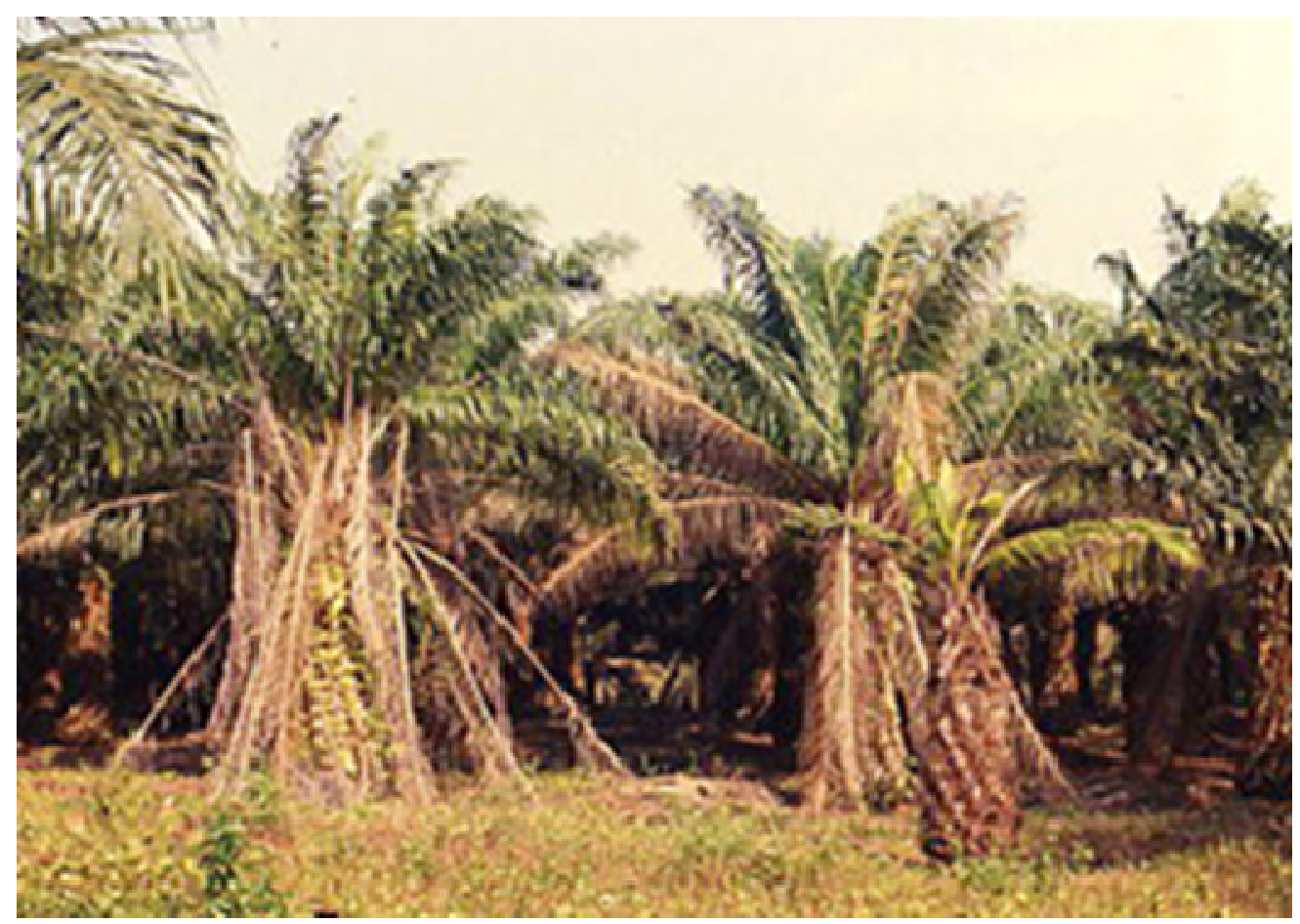

Figure 1. Acute symptoms of wilt disease.

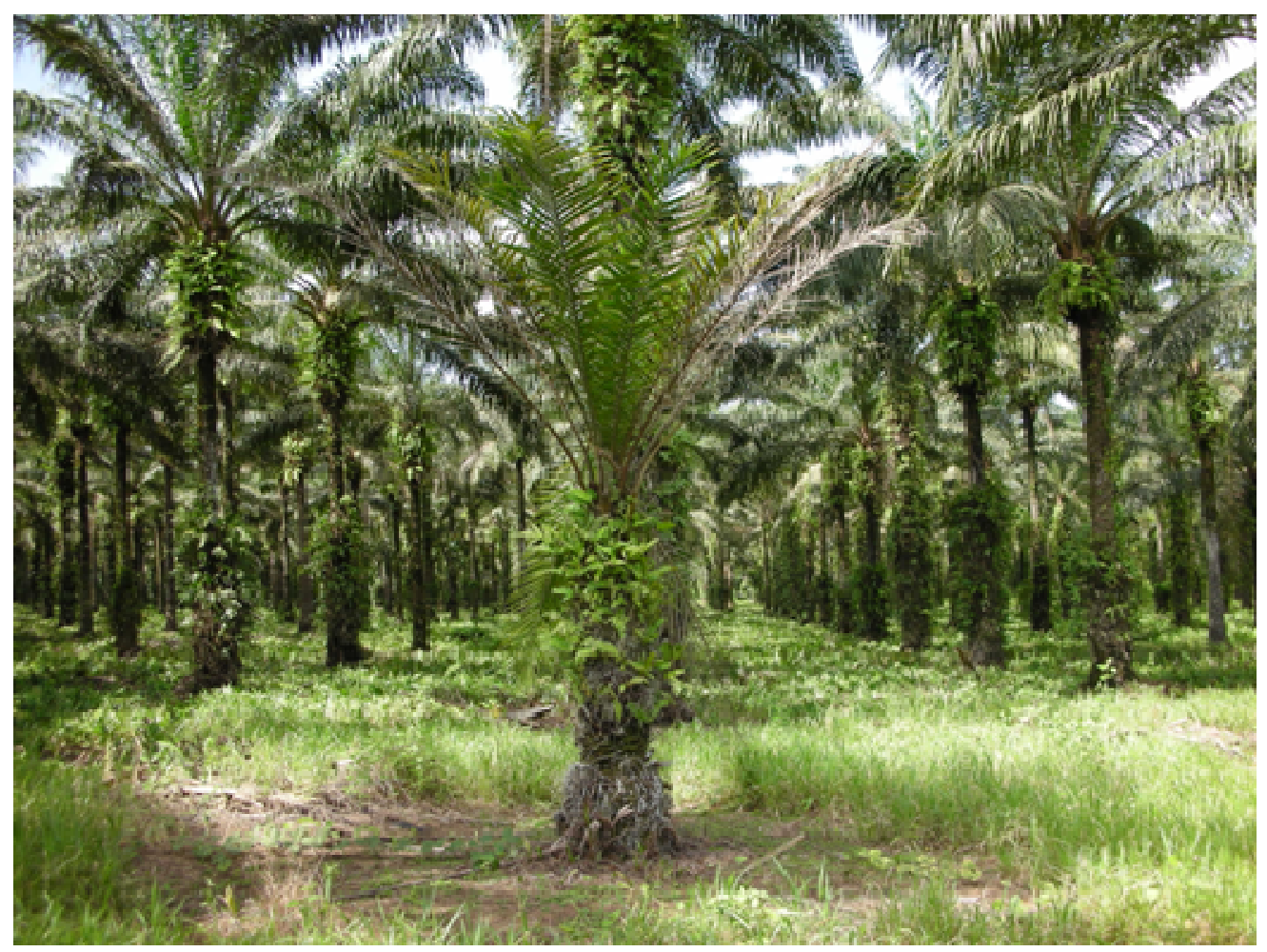

Figure 2. Chronic symptoms of wilt disease.

due to phenolic compounds which killed the pathogen or stopped its progression in the tissues of oil palm
(Diabate, 2008). The aim of this paper was to discriminate two tolerant clones and three sensitive clones from 
Table 1. Gradient programme for the high pressure liquid chromatography (HPLC) analysis.

\begin{tabular}{|c|c|c|}
\hline Time (min) & A (\%) & B (\%) \\
\hline 0 & 95 & 5 \\
5 & 95 & 5 \\
15 & 85 & 15 \\
30 & 85 & 15 \\
60 & 55 & 45 \\
75 & 10 & 90 \\
90 & 95 & 0 \\
\hline
\end{tabular}

their phenolic reaction after inoculation of the pathogen.

\section{MATERIALS AND METHODS}

\section{Biological material}

The material used was five oil palm clones. There were two tolerant clones: LMC 022, LMC 077 and three sensitive clones: LMC 96, LMC 074 and LMC 165. Each clone is represented by five seedlings. The vegetable organs studied were the roots and the pseudobulbs. The pseudobulb can be considered as the stipe of young palm tree at pre-nursery stage.

The liquid inoculum is developed from an aggressive stump of $F$. oxysporum f. sp. elaeidis isolated from an oil palm infected by wilt disease.

\section{Inoculation}

The seedlings were dug up in order to provoke injuries of the roots. The root system was cleaned with water and dipped in the liquid inoculum of $F$. oxysporum f. sp. elaeidis. Then the seedlings are pricked out in the compost. Five seedlings per clone were analyzed individually which corresponded to five repetitions per clone.

\section{Incubation periods}

The incubation periods were $T_{0}$ (immediately after inoculation), $T_{0}$ $+12 \mathrm{~h}$ (12 $\mathrm{h}$ after inoculation), $\mathrm{T}_{0}+24 \mathrm{~h}$ ( $24 \mathrm{~h}$ after). At the end of each period, each seedling was dug up giving on one hand a bunch of roots and on the other hand a pseudobulb; these two organs were weighed and preserved in the freezer.

\section{Extraction}

The roots and pseudobulbs originating from each sampling undergo were separately made in power with liquid nitrogen and were extracted during $40 \mathrm{~min}$ under reflux into $70 \% \mathrm{v} / \mathrm{v}$ aqueous ethanol. Each extract was then evaporated under reduced pressure at $40^{\circ} \mathrm{C}$ and was recovered into $10 \mathrm{ml} 70 \% \mathrm{v} / \mathrm{v}$ aqueous ethanol added with $0.1 \mathrm{ml} 2 \% \mathrm{v} / \mathrm{v}$ aqueous sodium metabisulfite at $2 \%$. The extracts were preserved in a freezer before analyses.

\section{High pressure liquid chromatography (HPLC) analysis}

The high pressure liquid chromatography (HPLC) was based on affinity differences in the compounds at a stationary phase consisting of silica microspheres on which were grafted carbon residues. The mobile phase was an aqueous solvent (solvent $A=$ water-acetic acid 1000-20), which progressively enriched itself at the organic stage (Solvent B = acetonitrile-water- acetic acid: 800-200-20), according to a programmable gradient. The chromatographic conditions were: flow rate of $0.8 \mathrm{ml} / \mathrm{min}$, and sample injection volume of $20 \mu \mathrm{l}$ extract. The gradient program was set as shown in Table 1. The run time of 90 min was set to elute all phenolic compounds that might be present in the clones of oil palm. The detection of the eluted compounds was done by a UV detector from 250 to 400 nanometer $(\mathrm{nm})$. The HPLC chromatogram corresponded to a set of peaks. The area of each peak was calculated by a peak integrator; the peaks corresponded to phenolic defence reaction and were used in statistical analysis. The HPLC system was coupled with barrette diode water 991 system which has given the UV spectrum of each peak from 250 to 400 nanometer (nm).

\section{Statistical analysis}

The data (peak areas) collected during this study were analysed respectively through Principal Component Analysis (PCA) on one hand and on the other hand Discriminant Analysis (DA) which is a technique for classifying a set of observations into predefined classes. The parameters chosen for the study were the variables measured on each organ (roots and pseudobulb) of clone studied. That is to say the area of the different peaks was obtained through High Pressure Liquid Chromatography analysis.

\section{RESULTS}

Phenolic profiles of oil palm clones after inoculation of $F$. oxysporum $\mathrm{f}$. sp. elaeidis

\section{Phenolic reaction of the pseudobulb}

The chromatogram (Figure 3 ) has shown that the pseudobulb extracts can be used to detect 15 peaks which characterised the phenolic compounds of this organ during $58 \mathrm{~min}$. Qualitatively, (Figure 4) the spectral characteristic of the peaks from 250 to $400 \mathrm{~nm}$ has shown that the best wavelength for detection of the phenolic products was $320 \mathrm{~nm}$.

\section{Phenolic reaction of the roots}

The chromatographic (HPLC) profile (Figure 5) revealed 15 peaks after an elution for $78 \mathrm{~min}$. That reading was carried out in the same conditions as the pseudobulbs. The Figure 6 corresponded to the spectral characteristics of the peaks from 250 to $400 \mathrm{~nm}$. The best wavelength for detection of the phenols was $320 \mathrm{~nm}$.

\section{Correlation between wilt index and phenolic profiles of roots and pseudobulbs}

\section{Multivaried analysis of the phenolic profiles obtained from the roots}

The results of the PCA analysis of oil palm's phenolic 


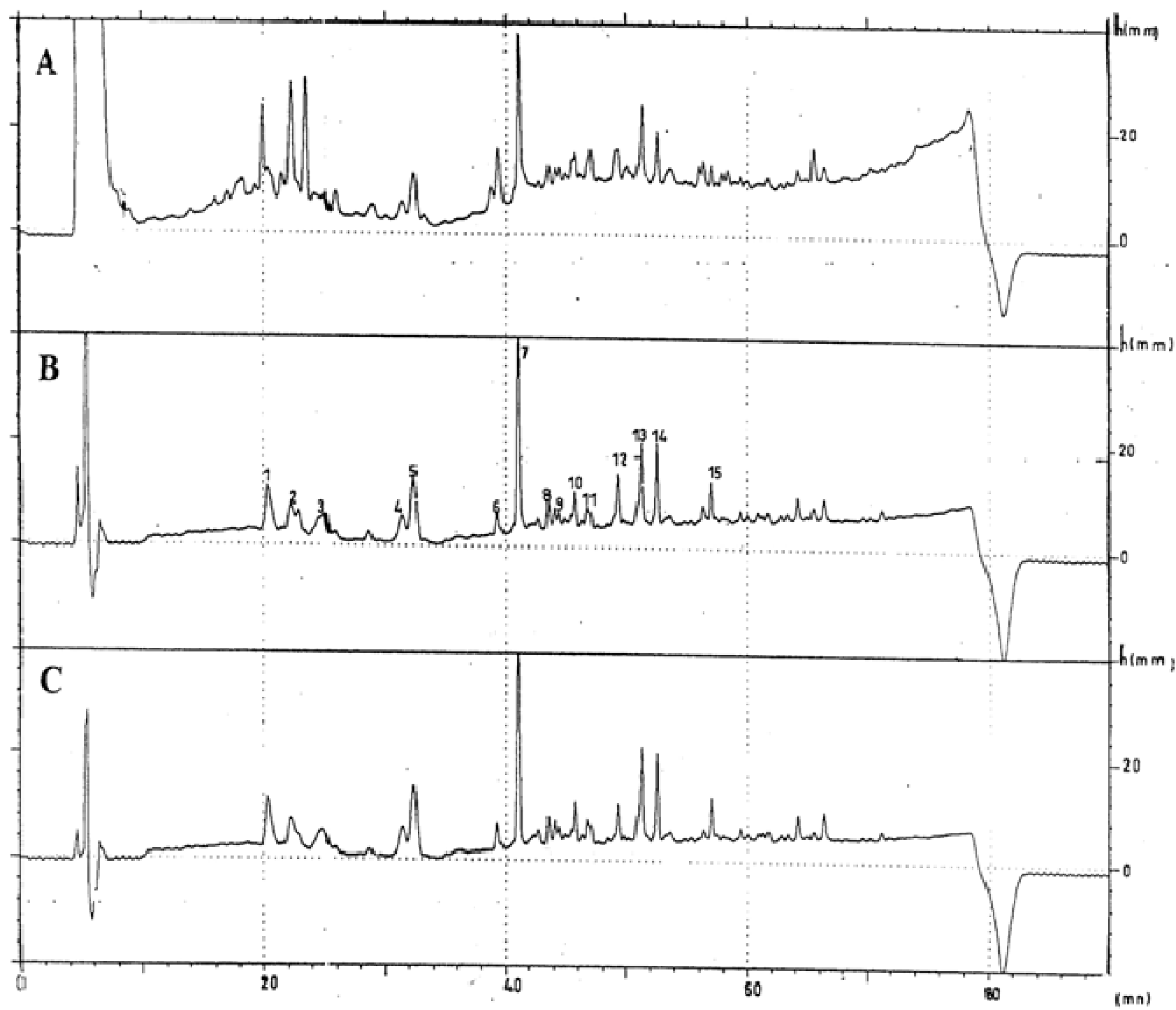

Figure 3. HPLC chromatogram of pseudobulb extract of palm detected on 3 wavelengths: $280 \mathrm{~nm}(\mathrm{~A}), 320 \mathrm{~nm}(\mathrm{~B})$ and $340 \mathrm{~nm}(\mathrm{C})$.

roots extract are presented in Figure 7 . A variety-related marking appeared in the tolerant clones 022 (1 T), 077 (4 T) and sensitive 096 (5 S); however, two sensitive clones, 074 (2 S) and 165 (3 S) were tightly superposed. This defect was provoked by the tolerant clone, 077 (4 T) which divided the ordination zone of the three sensitive clones. The fact remains that this organization has been strongly structured as testified by the correlation circle where the dominating variables were the peaks marked respectively as $2,3,11,10,6,7$ and 13 . The discriminant analysis (Figure 8) was carried out in accordance with three levels of tolerance classes defined below:

Class 1 (very tolerant clone): wilt disease index $b<$ or $=70$

Class 2 (intermediary clones): wilt disease index $>70<$ or $=140$
Class 3 (very sensitive clones): wilt disease index $>140$

The analysis has revealed a rather apparent delimitation of the classes; 1,2 and 3 . The distinction of classes 1 and 2 was made on the main axis 1: axis which inertia was the strongest. As for the delimitation $1+2$ compared with group 3, it was carried out on the weakest inertia axis, axis 2 . The discriminant variables were essentially the chromatographic variables 6, 10 and 11 .

\section{Multivaried analysis of the phenolic profiles obtained from pseudobulbs}

The results of PCA analysis of oil palm's phenolic extract of pseudobulb are presented in Figure 9. The performance of the clonal phenolic marking was envisaged; this 


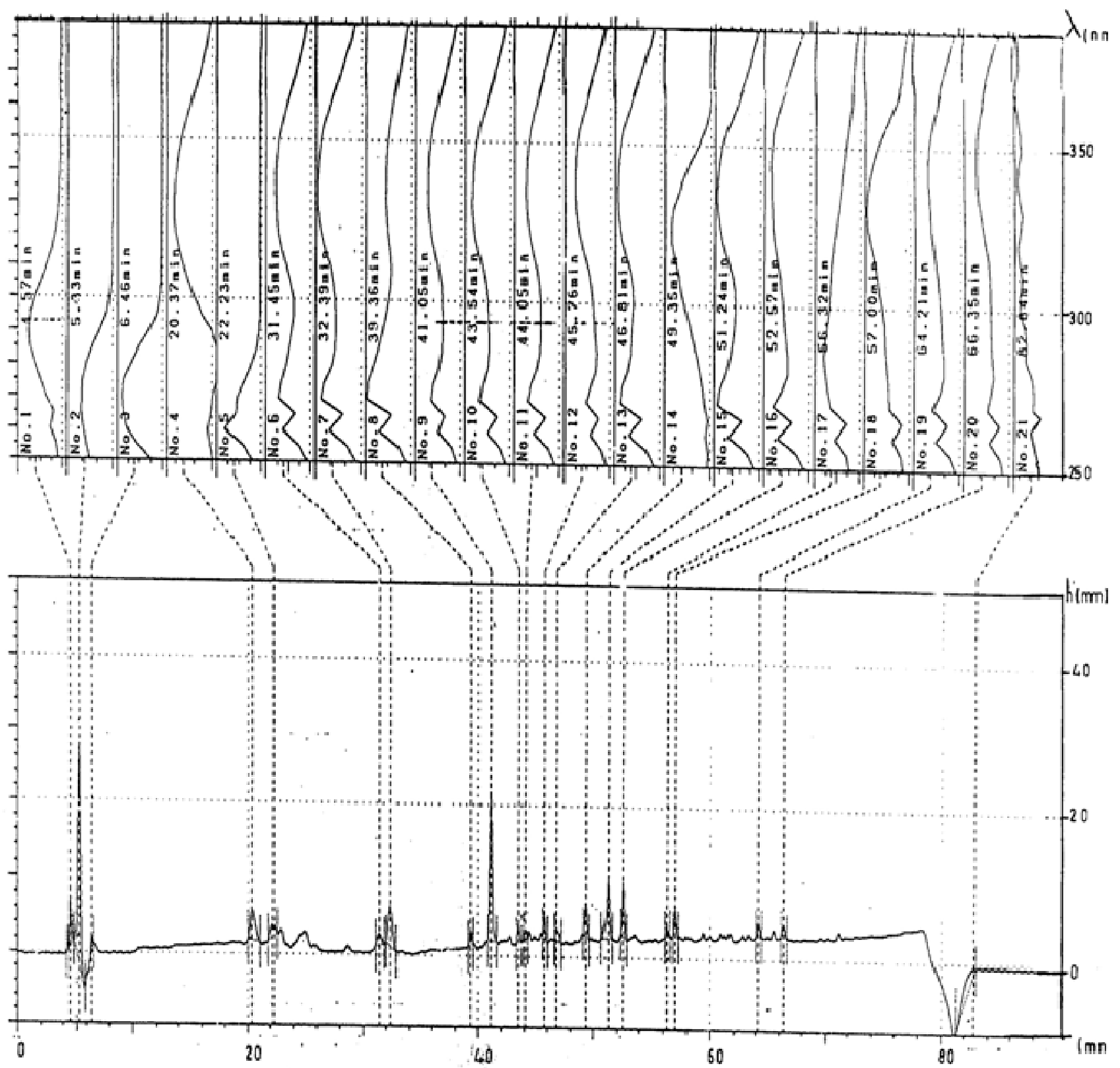

Figure 4. Spectral analysis of HPLC chomatogram of phenolic of extract of oil palm's pseudobulb.

performance has been significantly more important in the case of the pseudobulbs since the 5 experimented clones could easily be located for the most part by their representatives. The discriminant analysis (Figure 10) from the three classes has confirmed the PCA results by delimittating quite perfectly three sets corresponding to the three predefined tolerance classes. The ordination was done in accordance with the same rules as the ones defined for the roots; that is an opposition of the tolerance classes 1 and 2 on the axis 2 against class 3 and an opposition of the tolerance classes $1+2$ against class 3 on the axis 1 . The most discriminant variables were the peaks $5,9,11,13$ and 14 .

\section{DISCUSSION}

The main objective of this study was to show that the phenolic reaction of oil palm clones after inoculation by $F$. oxysporum f. sp. elaeidis could distinguish tolerant clones and sensitive clones.

In order to comprehend the individual variation of the phenolic content and keep only the variations actually linked to tolerance, we have studied the phenolic reaction of each single plant of clones. In fact, the response to the aggression of the pathogenic Fusarium could be a response located in the plant (Bioley et al, 1987; Brun, 1991). The methods used during this study have allowed 


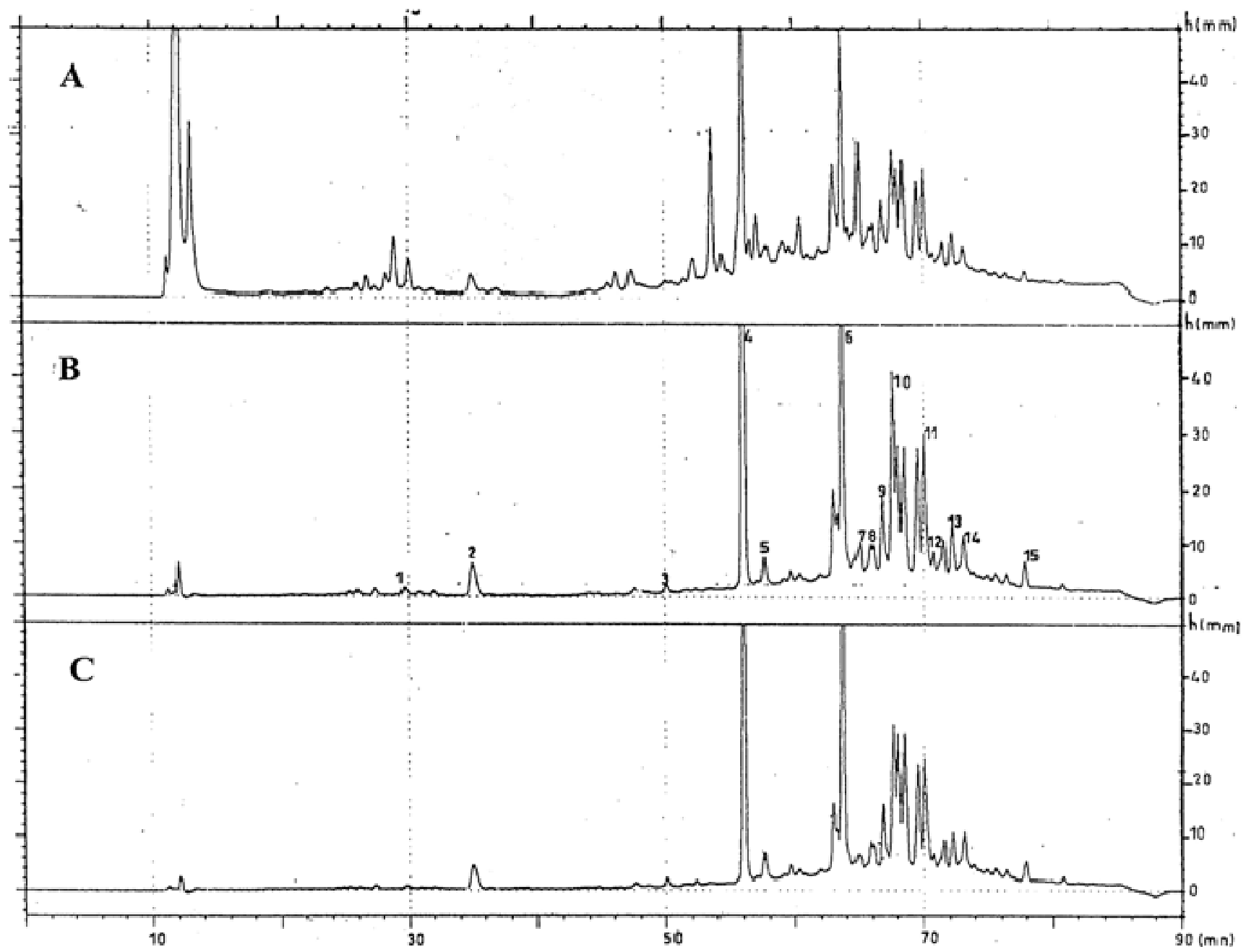

Figure 5. HPLC chromatogram of root extract of oil palm detected on 3 wavelengths: $280 \mathrm{~nm}(\mathrm{~A}), 320 \mathrm{~nm}(\mathrm{~B})$ and $340 \mathrm{~nm}(\mathrm{C})$.

us to access the soluble phenols in solution in the cell environment studied so far (Taquet, 1985; Diabaté, 1990) and also the phenols linked to the cell walls which role was acknowledged in the disease-resistance process (Ampomah and John 1988).

Concerning the comparison of phenolic metabolisms of the roots and pseudobulbs, the analysis of phenolic compounds of the oil palm seedlings was so far limited to the root phenols. Thus, the concentration of the phenolic compounds by HPLC have permitted the clones classification according to their ability to synthesize phenols during infection. Essentially, this classification has added up the one concerning the behaviour of the planting stocks with respect to wilt disease after the precocious tests at prenursery (Taquet et al., 1985). The acceleration of phenolic bio-syntheses following the infection was more often important in the resistant host than in the sensitive one. And yet, the reaction of sensitive plants to the inoculation of the F. oxysporum f. sp. elaeidis at prenursery corresponded notably to a browning of the vascular fibres at the level of the pseudobulb. It was the reason why we have taken into account the pseudobulb in this study. Thus, a qualitative comparison of the roots and pseudobulb has revealed two rather different metabolisms. Almost all the pseudobulbs chromatographic information was obtained in $58 \mathrm{~min}$ while at the same time the roots were still at the chromatographic peak number 5 . Finally, the spectral analysis of the phenolic peaks (of HPLC) has shown that the majority of the roots and pseudobulbs metabolic information resulted from the phenylpropanoids way. The phenolic metabolism of the pseudobulbs gave way to the accumulation of more hydrophilic products than in the roots where lipophilic phenols predominated. The best wavelength detection in both cases was $320 \mathrm{~nm}$. Moreover, the tolerant-genotype and sensitive-genotype screening was facilated with respect to the roots. Therefore, our results justified the choice of the two organs as vegetable or biological matter in the assessment of the physiological mechanisms of the oil palm resistance to wilt disease.

The study of the phenolic compounds elaborated during the defence reaction in the clones of oil palm as well as in 


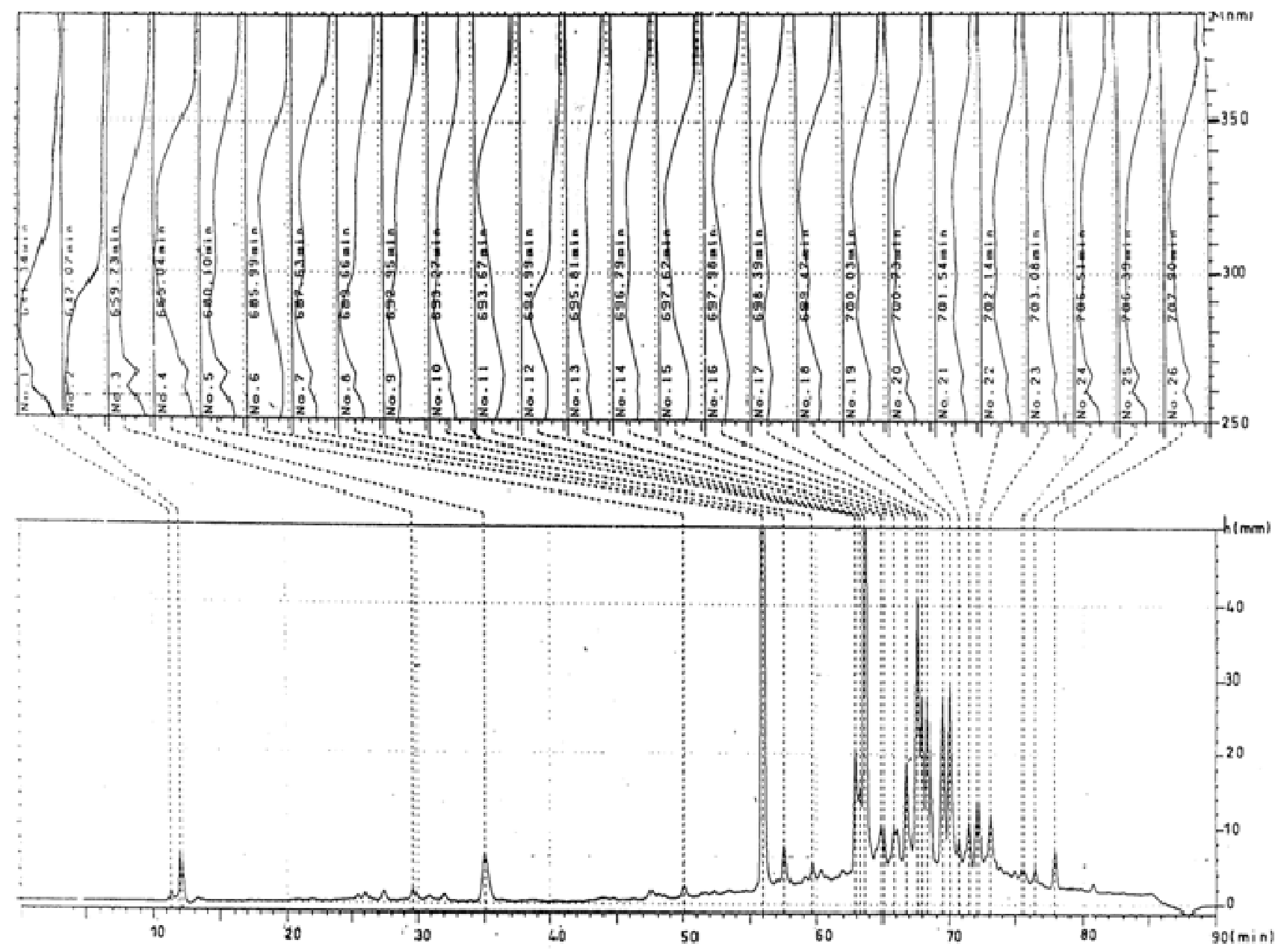

Figure 6. Spectral analysis of HPLC chromatogram of phenolic extract of oil palm's roots.

other vegetables has shown the diversity of these phenolic products in reaction to wilt disease. The use of High Pressure Liquid Chromatography in our researches allowed us to confirm the predominance of the phenolic compounds. Three hypotheses can be envisaged about the accumulation of the phenolic compounds in the organs infected by $F$. oxysporum f. sp. Elaeidis. On one hand, their synthesis could be initiated or stimulated after the penetration in the roots by $F$. oxysporum f. sp. Elaeidis. On the other hand, their biodegradation in the infected tissues would be likely to be reduced, or even differed due to metabolic modifications in the host. Thus, researches have shown that $F$. oxysporum f. sp. elaeidis is implicated in vitro degradation of several fongitoxic substances elaborated by the oil palm (Diabaté, 1992; et Traoré, 2002). Moreover, the inhibition of the defence reaction was made possible by the application of a synthesis flow inhibitor of phenylpropanoids, the a aminooxyacetic acid (AOA) at the level of the roots of young palm trees inoculated by $F$. oxysporum f. sp. elaeidis (Taquet et al., 1985). The stimulation of the syntheses of the phenolic compounds with biotic elicitors has been demonstrated (Taquet et al., 1985). Thus, the arachidonic acid and to a lesser extent, the galactosamine, stimulates the defence reactions of the oil palm infected by F. oxysporum f. sp. elaeidis. Finally, the phenolic compounds seem to be synthesized in a major way during the elicitation reaction. Nevertheless, Taquet et al. (1985) have shown that in the absence of the pathogenic agent, the accumulations of resistance factors were practically undetectable in the tissues. The response of the host to the elicitation would therefore imply the dependence of two metabolisms confrontation, the palm tree one, and the F. oxysporum f. sp. elaeidis one.

The hypothesis formulated by Moreau et al., (1982) on the basis of studies about vascular diseases of carnation has allowed us to understand the aggression process of F. oxysporum f. sp. elaeidis in the tissues of the sensitive or tolerant oil palm. Indeed, the installation of F. oxysporum f. sp. elaeidis would be so quick in the tissues of the vascular parenchyma that there would be only a weak production of endogenous elicitors by the oil palm. The 


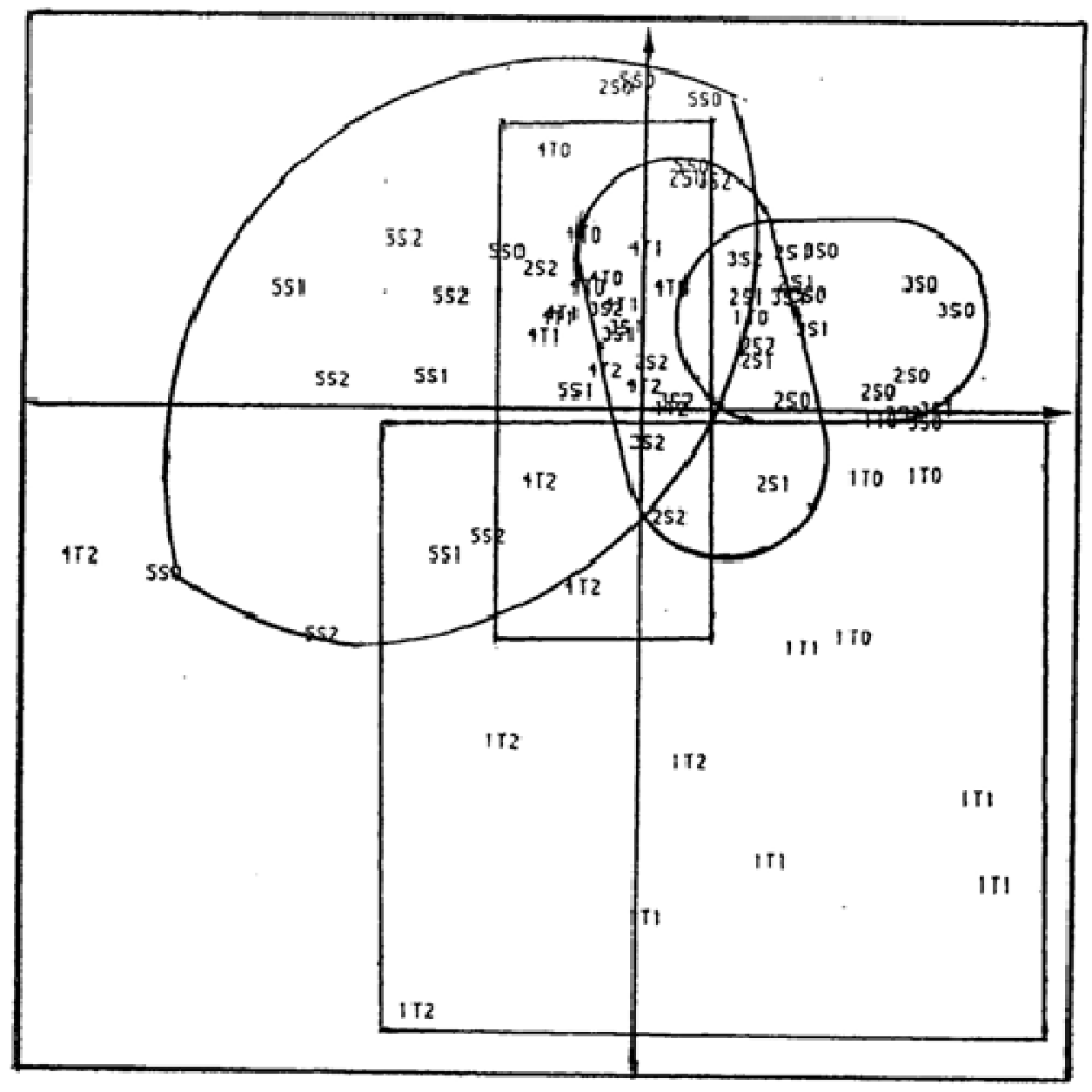

ACP 1/2 R PHVTO 64

\% inertie: 43,5

$\mathrm{I}=$ clane 022

$2=$ clane 074

$3=$ clone 165

$4=c$ lone 077

$5=$ clone 096

$T=$ tolérant

$S=$ sensible

$0=$ TO

$1=\mp 12$ heures

$2=\mathrm{T} 24$ heures

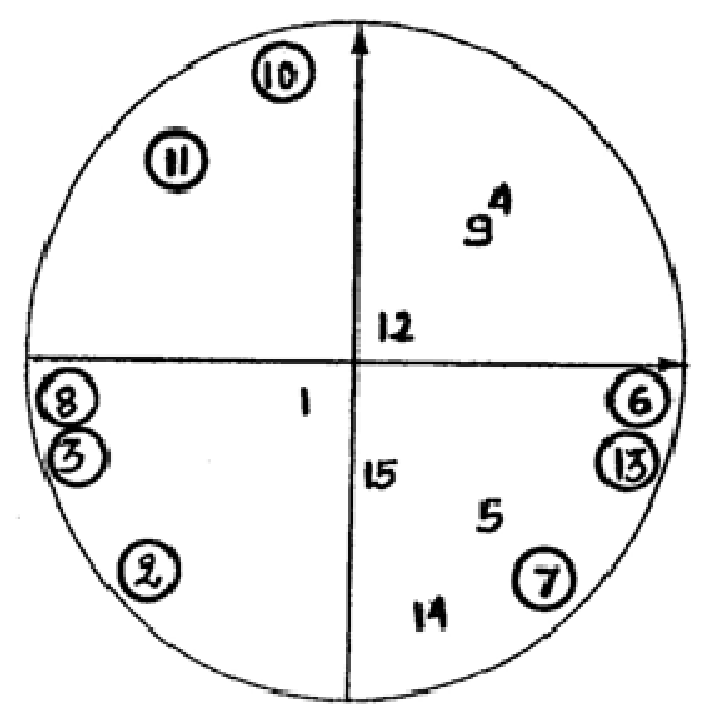

Figure 7. PCA analysis of results of oil palm's phenolic roots extract.

defence mechanisms of the oil palm might be weakened.

Finally, the hypothesis about the suppression of the oil palm resistance through repressors elaborated by $F$. oxysporum f. sp. elaeidis was conceivable in the oil palm.
Studies comparing the action of Phytophthora infestans wall fragments on one hand, and the ones of glucans extracted from the same walls and soluble in water on the other hand, on the hypersensitivity reaction of the host 


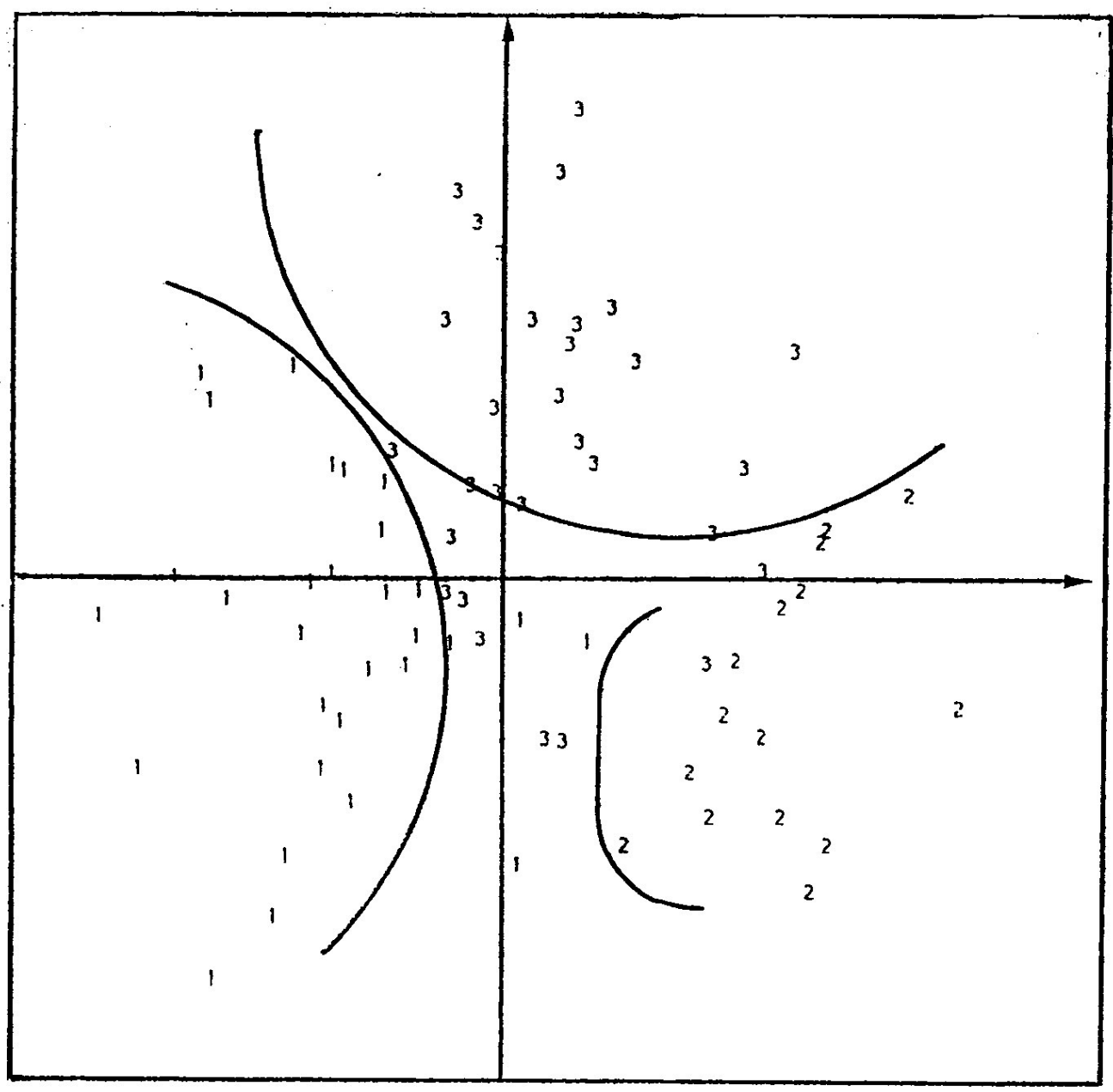

AD R PHYTO 64
$\%$ inertie : 100
$1: i<70$
$2: 70<i<140$
$3: 140<i$

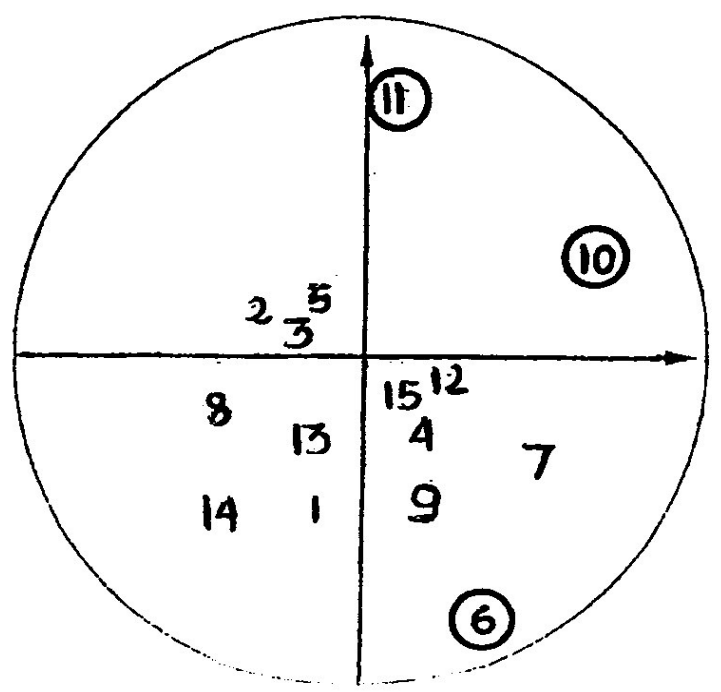

Figure 8. DA analysis of results of oil palm's phenolic roots extract.

plants have led to divergent results (Doke, 1979; Doke et al., 1980). The first ones would act as specific elicitors particularly in the solanaceae and the leguminous plants, while the second ones might eliminate the hypersensitive reaction.

These hypotheses have proved therefore that the plants could react during the infection, to a specific group of parietal composite. According to Hadwiger and Adams 


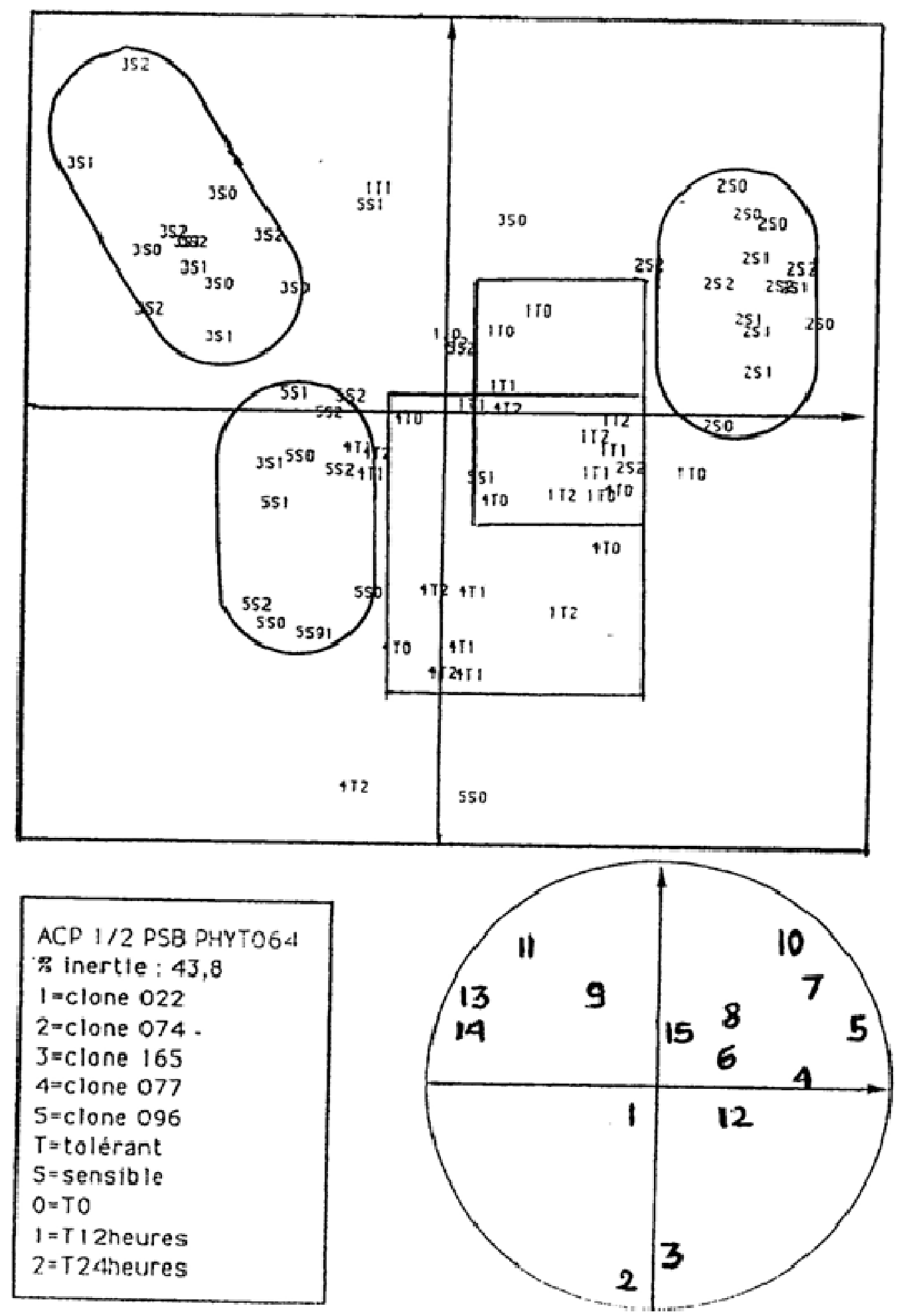

Figure 9. PCA analysis of results of oil palm's phenolic extract of pseudobulb.

(1978), the balance between elicitor and repressor noticed in the Fusarium solani, the pathogenic agent of the pea can be used to explain the differences in response of the oil palm clones after inoculation by F. oxyspo- rum f. sp. elaeidis. The specificity of the defence reaction would seem to be especially important only if the resistance factors pile up quickly and in great quantity in tissues of clones infected by the $F$. oxysporum f. sp. 


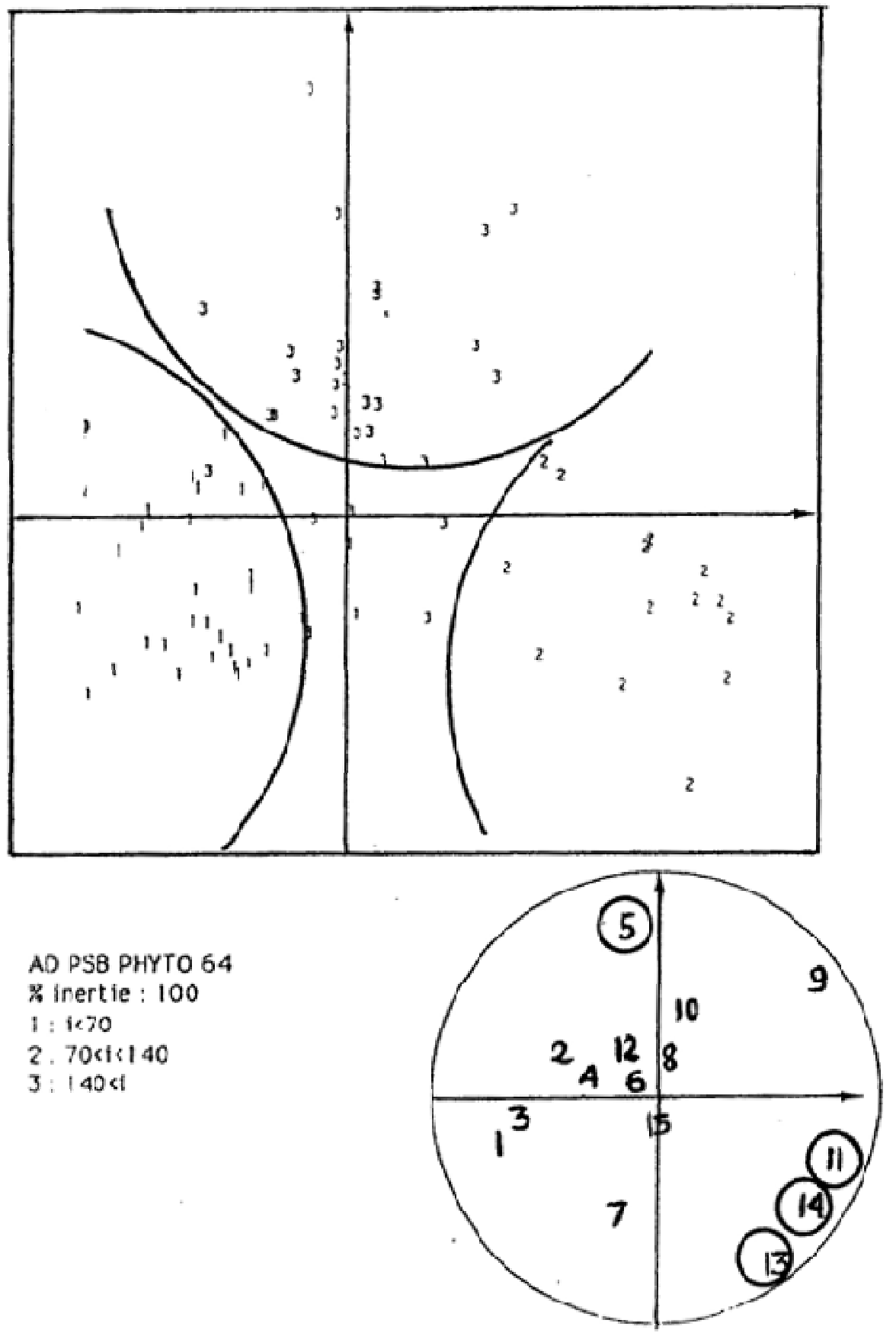

Figure 10. DA analysis of results of oil palm's phenolic extract of pseudobulb.

elaeidis (Zhu and Yao, 2004; You et al., 2005). Our results are in favour of this hypothesis with the tested clones. The in vitro biodegradation by F. oxysporum f. sp. elaeidis of hydrophilic and lipophilic phenolic compounds elaborated by the oil palm tends to prove that the defence reaction owes its effectiveness to new syntheses of the phenolic compounds which may be phytoalexins (owned flavonoids), hence their permanent stimulations during the oil palm growth.

\section{Conclusion}

The physiology of the oil palm is modified during the root aggression by $F$. oxysporum f. sp. elaeidis through the synthesis of phenolic compounds in infected tissues. The aim of our study was to compare the phenolic reaction of the roots and the pseudobulb after inoculation of the pathogenic Fusarium, in order to better discriminate between tolerant clones and sensitive ones. The results have 
shown that in reaction to the aggression of the pathogenic agent of wilt disease, the hydrophilic and lipophilic phenolic compounds were strongly stimulated in the tissues of the infected clones. The observation of the spectrums of these compounds revealed that those phenols belonged to the family of the flavonoids noticed here in the oil palm for the first time. Concerning the organs, the study has shown that the defence phenolic reaction was developed in the roots as well as in the pseudobulb and often more in the latter, for the pathogens moving throughout the sap, would arrive quite quickly in the foliar sheath named here pseudobulb.

\section{REFERENCES}

Ampomah Yaw A, John F (1988). Insoluble phenolic compounds and resistance of potato tuber disc to Phytophthora and Phoma. Phytochem. 27(8): 2533-2541.

Bachy A, Fehling C (1957). La fusariose du palmier à huile en Côte d' Ivoire. J. Agric. Trop. Bot. Appl. 4: 228-240.

Bioley JP, Jay M, Fiasson JL (1987). Mécanismes biochimiques du métabolisme secondaire dans la réaction des végétaux cultivés aux pathogènes fongiques. Informations techniques CETIOM, 101(4-7): $p$. 19

Brun N (1991). Les tannins de la féverole (Vicia faba L., Leguminosae) : diversité chimique et variétale. Mémoire de Doctorat. Université Claude Bernard. Lyon, I: p. 159

Diabate S Taquet B, Renard JL, De Franqueville H. Et Reiser P (1990). Analyse en CLHP des substances produites par le palmier à huile au cours de l'infection par le Fusarium oxysporum f. $\mathrm{sp}$. elaeidis. Perspective pour la sélection. Oléagineux, 45(2): 49-55.

Diabate S, Ledeme P, De Franqueville H, Et Kouame B (1992). Effect d'une souche avirulente de Fusarium oxysporum sur l'expression la fusariose et sur les propriétés fongitoxiques des extraits racinaires de palmier à huile. In: Intreaction Plantes-Microorganismes, IFS: pp. 307320.

Diabate $S$ (2008). Contribution à l'étude de la diversité phénolique dans la réaction de défense du palmier à huile (Elaeis guineensis jacq) contre la fusariose vasculaire. Thèse de Doctorat de l'Université de Cocody (Abidjan). p.155

Doke N (1979). Hypersensitive reactivity of various host and non host plant leaves to cell wall components and soluble glucan isolated from Phytophthora infestans. Ann. Phytopathological Soc. Jpn. 45(3): 386393.
Doke N, Garas NA, Kuc J (1980). Effects on host hypersensitivity of suppressors released during the germination of Phytophthora infestans cystospore. Phytopathol. 70: 35-39.

De Franqueville H, Renard JL (1990). Bilan de l'amélioration du niveau de la tolérance du palmier à huile à la fusariose. Evolution de la maladie sur la plantation R. Michaux. Oléagineux, 45(10): 399-405.

Hadwiger LA, Hadams JM (1978). Nuclear changes associated with the host parasite interaction between Fusarium solani and peas. Physiol. Plant Pathol. 12: 63-72.

Meunier I, Renard JL, Quillec G (1979). Hérédité de la résistance à la fusariose chez le palmier à huile. Elaeis guineensis Jacq. Oléagineux, 34 (12): 555-561.

Moreau M, Catesson AM, Et Duval JC (1982). Réponse des cellules contiguës aux vaisseaux selon la nature de l'agression. CR. Acad. Sci. Paris, 294: 553-556.

Renard JL, Noiret JM, Meunier J (1980). Sources et gammes de résistance à la fusariose chez le palmier à huile. Elaeis guineensis et Elaeis melanococca. Oléagineux, 39(8-9): 387-393.

Renard JL, Quillec G (1984). Les maladies graves du palmier à huile en Afrique et en Amérique du sud. Oléagineux, 39(2): 57-63.

Taquet B (1985). Les mécanismes physiologiques de la réaction de défense du palmier à huile contre la fusariose vasculaire. Application à la recherche de nouveaux moyens de lutte. Thèse de Doctorat 3è cycle. Paris, p. 151.

Taquet B, Renard JL, Vernenghi A, Diabate S, Subbarao PV, Pelletier A, Ravise A (1985). Essai de stimulation de la tolérance du palmier à huile à la fusariose vasculaire par application d'éliciteurs.Fungicides for crop protection- BCPC. Monograph, 31: 289-292.

Traore A (2002). Fusariose vasculaire du palmier à huile: étude épidémiologique en champ et microanalyse des composés de défense. Mémoire pour l'obtention du Diplôme d'Agronomie Approfondie. ESA Yamoussoukro, p. 78.

You MP, Barbetti MJ, Nichols PGH (2005). New Trifolium subterraneum genotypes identified with resistance to race 2 of kabatiella caulivora and cross resistance to fungal root rot pathogens. Aust. J. Agric. Res. 56: $1111-1114$.

Zhu H, Et Yao Q (2004). Localized and systemic increase of phenols in tomato roots induced by Glomus verisiforme inhibits Ralotronia solanacearum. J. Phytopathol. 152: 537-542.

Wardlaw CW (1946). A wilt disease of oil palm. Nature, London, pp. 158-256. 